\title{
Lo que invocar la figura del Rey y la justicia regia significaba (y lo que no) Monarquismo popular en Charcas tardocolonial
}

\section{What Invoking the King's Name and Royal Justice Meant (and What it Did Not)}

Popular Royalism in Late Colonial Charcas

SERGio SERULNIKOV ${ }^{1}$ http://orcid.org/0000-0001-9709-8582

${ }^{1}$ Universidad de San Andrés-Conicet

Vito Dumas, 284, Vitoria, Buenos Aires, B1644BID, Argentina

sserulnikov@udesa.edu.ar

RESUmen El artículo explora las expresiones de monarquismo popular entre sectores indígenas y plebeyos urbanos en Charcas a fines del siglo XVIII. Analiza los fundamentos ideológicos de acciones colectivas, representaciones simbólicas y prácticas políticas que invocaban la imagen del rey. Se basa en eventos tales como las grandes rebeliones tupamaristas y kataristas, varias protestas en La Plata (hoy Sucre) en la década de 1780 y el levantamiento de la ciudad en 25 de Mayo de 1809. El argumento central es que en Hispanoamérica colonial el Rey era un significante vacío. En la medida que carecía de todos los atributos materiales asociados a magistrados y organismos de gobierno, podía ser evocado para transmitir aquiescencia al orden establecido tanto como para subvertir radicalmente las relaciones de poder en el que ese orden su fundaba. Por consiguiente, las implicancias profundas del legitimismo monárquico no debieran ser inferidas de los pronunciamientos formales y las declaraciones de principios sino del contexto político de las acciones colectivas y su inscripción en la esfera pública.

Recibido: 19 jul. 2018 | Revisto por el autor: 19 sept 2018 | Aprobado: 03 oct. 2018 http://dx.doi.org/10.1590/0104-87752019000100003

Varia Historia, Belo Horizonte, vol. 35, n. 67, p. 37-82, jan/abr 2019 
Palabras Clave monarquismo popular, colonialismo, Charcas, historia política

Abstract The article addresses expressions of popular monarchism among Indians and urban groups in late colonial Charcas. It explores the ideological underpinnings of collective actions, symbolic representations, and political practices that invoked the King's image. It draws from various historical events such as the Tupac Amaru and Katarista indigenous rebellions, popular protests in the city of La Plata (present-day Sucre) in the 1780s, and the Charcas uprising of May 25, 1809. The central argument is that in Spanish America the king was an empty signifier. As the King's image lacked all the material and symbolic attributes associated with government officials and bodies, it could be deployed to convey compliance to the existing political order as well as to subvert in radical ways the relations of power on which that order was predicted. Therefore, the profound implications of monarchical legitimacy cannot be inferred exclusively from formal statements, programs, and declarations of principles but from the political nature of the collective practices and their inscription into the public sphere. KEYWORDS popular monarchism, colonialism, Charcas, political history

Por añadidura, las palabras del Emperador eran por regla general ambiguas y poco claras ... El que estaba a cargo del Ministerio de la Pluma era la persona de más confianza del Emperador y tenía un poder enorme. Podía convertir las nebulosas cábalas verbales del Monarca en cualquier disposición ... Era la personalidad más odiada de la corte, pues la opinión pública, convencida de la sabiduría y bondad del Digno Señor, culpaba precisamente al ministro de tomar decisiones malignas y estúpidas, las cuales eran incontables. Aunque también es cierto que la servidumbre se preguntaba sotto voce por qué Haile Selassie no cambiaba de ministro, pero en palacio las preguntas solo se podían hacer de arriba abajo, nunca al revés. Precisamente en el momento en que por primera vez sonó una pregunta planteada en dirección opuesta a la acostumbrada sonó también la señal de la revolución. (Kapuściński, 2004, p.16-17). 
La finalidad del artículo es explorar las expresiones de monarquismo popular entre los sectores indígenas y los grupos urbanos de Charcas a fines del siglo XVIII. Procura discernir los fundamentos ideológicos de acciones colectivas y representaciones simbólicas que invocaban la imagen del rey y apelaban a la justicia española con fines contenciosos. La pregunta que organiza el texto es cómo definir el significado político último de tales manifestaciones. ¿Son fenómenos orientados a restaurar un mundo tradicional, a remediar la percibida violación de derechos ancestrales, o pudieron acarrear una ruptura radical con el sistema de dominación? Para responde estos interrogantes, nos focalizamos en eventos tan dispares como las grandes rebeliones tupamaristas y kataristas de 1780-1782, el ceremonial público en la ciudad de La Plata (hoy Sucre) en la década de 1780 y, más sucintamente, el levantamiento ocurrido en la ciudad el 25 de Mayo de 1809 en respuesta a la situación de vacancia regia generada por la ocupación francesa de la península Ibérica. No es nuestro propósito ahondar en cada uno de estos acontecimientos o ofrecer nuevas evidencias empíricas, lo cual excedería con largueza las posibilidades de un artículo. Nos interesa más bien pensarlos transversalmente desde este ángulo. Antes de adentrarnos en los casos, nos detendremos en algunas aproximaciones teóricas al problema de la relación entre tradición y novedad, así como en la producción historiográfica sobre el monarquismo popular y los usos de la ley en las sociedades americanas y europeas de Antiguo Régimen.

En su formulación más abstracta, el argumento central que planteamos es que en Hispanoamérica colonial el rey era un significante vacío. Presuponía desde luego el reconocimiento de una fuente externa y superior de autoridad que corporizaba en su persona, o mejor dicho su figura, la unidad de los muy variados cuerpos políticos que conformaban la monarquía. Pero en la medida que, debido al origen trascendente de su poder y su inconmensurable lejanía, carecía de todos los atributos materiales asociados a las magistraturas y organismos de gobierno, podía ser conjurado para transmitir aquiescencia al orden establecido tanto como para subvertir las relaciones de dominación en el que ese orden se fundaba. Significante vacío no quiere decir pues que 
la proclamada fidelidad a la Corona nada significara sino que su significado era indeterminado: denotaba cosas muy distintas para distintos actores y para los mismos actores a lo largo del tiempo. Más importante aún, no imponía constreñimientos sobre los horizontes ideológicos. Así parecen demostrarlo, por caminos muy diferentes entre sí, las dos grandes crisis generales del dominio español en los Andes tardocoloniales los movimientos indígenas de 1780 y los movimientos autonomistas de 1809. Observados desde este punto de mira, surge que la sistemática horadación de las formas establecidas de hacer política terminó por poner en discusión las bases de legitimidad de la propia autoridad soberana que los insurgentes invocaban para legitimar sus acciones colectivas y anhelos de cambio. En nombre de la putativa voluntad regia y el debido funcionamiento de sus instituciones, se desnaturalizaron presupuestos heredados e hicieron imaginables sistemas alternativos de gobierno. Por consiguiente, las implicancias profundas del legitimismo monárquico no debieran ser inferidas de los pronunciamientos formales y las declaraciones de principios, de la axiomática devoción al rey y a la tradición, sino del contexto de las prácticas y su inscripción en la esfera pública.

\section{TRADICIÓN Y NOVEDAD}

¿Cómo nace lo nuevo? ¿Cómo surgen y consolidan nuevos modos de entender las relaciones con el poder, nuevos mecanismos de representación y nuevas prácticas políticas? Son interrogantes que han siempre concitado la atención de las investigaciones sobre el ocaso del Antiguo Régimen y que hacen al objeto central de este artículo - el significado del monarquismo popular en el mundo colonial hispanoamericano. Resulta provechoso por la tanto comenzar repasando algunos de los problemas interpretativos generales del fenómeno. Puede decirse que la declinación de las sociedades de Antiguo Régimen ha sido usualmente pensada en términos de la irrupción de novedades radicales en los sistemas de pensamiento (la filosofía de la ilustración, el liberalismo), en las identidades colectivas (nacionales, de clase, raciales) o en las formas de circulación de las ideas (periódicos, panfletos, crítica literaria). Lo nuevo es concebido 
en oposición a lo heredado, aunque naturalmente lleve muchas de sus marcas. Quien acaso más elocuentemente articuló esta noción fue Karl Marx en su famosa apertura del El 18 Brumario de Luis Bonaparte. "La tradición de todas las generaciones muertas oprime como una pesadilla el cerebro de los vivos", escribió allí. "Y cuando éstos aparentan dedicarse precisamente a transformarse y a transformar las cosas, a crear algo nunca visto, en estas épocas de crisis revolucionaria es precisamente cuando conjuran temerosos en su auxilio los espíritus del pasado, toman prestados sus nombres, sus consignas de guerra, su ropaje, para, con este disfraz de vejez venerable y este lenguaje prestado, representar la nueva escena de la historia universal" (Marx, 2003, p.10). Lo que Marx sugiere es que lo viejo tiene por fuerza un lugar en la emergencia de lo nuevo, pero solo en condición de lastre, o de coartada, una prótesis que requiere el recién nacido en sus primeros pasos.

En un ensayo titulado "The Radicalism of Tradition", Craig J. Calhoun ha apuntado, con razón, que este célebre aserto participa en verdad de una dicotomía más amplia, de origen iluminista, que establece un hiato tajante entre tradición y modernidad, orden y ruptura, reacción y revolución. Es una visión binaria que subyace en paradigmas interpretativos de muy diversas orientaciones teóricas y campos disciplinares. El más formidable análisis del nacimiento de la sociedad burguesa, Historia y crítica de la opinión pública. La trasformación estructural de la vida pública de Jürgen Habermas, ha sido pasible de este tipo de crítica. También lo fue, a su manera, la obra de mayor influencia en las últimas tres décadas sobre la crisis de la monarquía española, Modernidad e independencias. Ensayos sobre las revoluciones hispánicas de François-Xavier Guerra (enseguida volveremos sobre este punto). Es de notar, sin embargo, que existe una rica y variada corriente de estudios que han recobrado el potencial transformador de prácticas, discursos e instituciones ancladas en un pasado distante. Es el caso, para tomar unos pocos ejemplos, de las investigaciones sobre los orígenes de la opinión pública en la Francia borbónica (Chartier, 1995; Farge, 1992), el decisivo peso de los gremios de artesanos y la cultura política plebeya en el surgimiento del movimiento obrero (Thompson, 1989; 
Sewell, 1980; Ranciere, 1993) o la historia conceptual (Koselleck, 1993; Skinner, 1979). Calhoun mismo muestra cómo en los albores del mundo industrial, comunidades de corte tradicional como los organismos municipales, las cofradías y corporaciones de variado tipo, actuaron como núcleos organizacionales de profundas impugnaciones al orden establecido. La clave para discernir el paso de protestas reactivas a políticas sediciosas radica siempre en las circunstancias subyacentes. Es el entorno, más que el contenido de las ideas o las modalidades de acción, lo que define su significado.

En momentos en que el orden existente parece profundamente amenazado - puntualiza Calhoun - tales comunidades podrían encontrar que pueden ser tradicionales solo siendo radicales... Los radicales reaccionarios raramente, si alguna vez, han tenido la supremacía en las revoluciones. Pero al mismo tiempo, las revoluciones dignas de ese nombre nunca fueron llevadas a cabo sin ellos (Calhoun, 1983, p.911). ${ }^{1}$

Esta compleja imbricación entre tradición y novedad se puede apreciar con nitidez en la producción de petitorios impresos durante la Revolución Inglesa del siglo XVII, un fenómeno de múltiples resonancias para nuestra inquisición acerca de los usos populares de la imagen del monarca y el derecho. Los enfrentamientos del Parlamento, los grupos puritanos y las clases bajas con el régimen absolutista de los Estuardos propiciaron la proliferación de un antiguo dispositivo comunicacional proveniente del medioevo como las peticiones al monarca. En un escenario de formidable polarización política, no obstante, la práctica adquirió inauditas connotaciones. Como sostiene David Zaret, tradicionalmente los petitorios se limitaban a transmitir agravios locales al poder central conforme a normas universales de secretismo que proscribían todo debate público sobre asuntos de gobierno. Durante las guerras civiles, por el contrario, los escritos tendían a deslizar juicios normativos sobre la voluntad del pueblo, a interpelar a la opinión pública y a ser

1 Las traducciones al español son del autor. 
la voz de agrupaciones electivas en vez de cuerpos corporativos. Nada era más ajeno y corrosivo al mundo heredado. Y aun así, lo propio de estas novedosas modalidades de petición, su rasgo distintivo, consistía en denegar su carácter novedoso. Ese era uno de sus principales móviles. "Los tradicionales elementos retóricos de las peticiones fueron un medio para denegar la innovación", afirma el autor.

Los contemporáneos defendían las peticiones que valoraban en tanto formas deferenciales, jurídicas y espontaneas de queja - el recurso retórico que despolitizaba las quejas en las consuetudinarias peticiones $-\mathrm{y}$ atacaban aquellas que reprobaban exponiendo las prácticas organizacionales que contradecían sus apariencias apolíticas.

En este tipo de sociedades, en suma, las pugnas por la legitimidad consistían en despolitizar las posiciones propias y politizar las ajenas. Detrás de esta presunta incongruencia no hay una mera contradicción lógica o simples cálculos pragmáticos, sino lo que denomina "la paradoja de la innovación": "una común ocurrencia por el cual los individuos no reconocen el tipo innovador de comportamiento del que participan" (Zaret, 1996, p.1499-1500, p.1502). Estamos así en presencia de intervenciones públicas irreductibles al régimen político vigente, que afloran inicialmente a nivel de la praxis social, no están sancionadas por marcos conceptuales prexistentes y cuya justificación ideológica descansa en atenuar todo lo que de extraño y antitético al orden establecido pudieran tener: en negar lo que son.

Más próximo a nuestro objeto de estudio, también las controversias acerca del papel del pensamiento político castellano en el proceso de independencia hispanoamericano iluminan este punto. En su pionera obra de 1961, Tradición política española e ideología revolucionaria de Mayo, Tulio Halperín Donghi argumentó que las ideas a las que en principio apelaron los dirigentes criollos remitían al antiguo pactismo hispánico más que al universo conceptual de la ilustración francesa o el liberalismo anglosajón, como postulaba el canon historiográfico originado en el romanticismo nacionalista del siglo XIX. Es una 
interpretación afín a la planteada posteriormente por François-Xavier Guerra en su citado libro, Modernidad e independencias. Ensayos sobre las revoluciones hispánicas, y la llamada corriente revisionista que se desarrolló a partir del mismo. Existe sin embargo una crucial diferencia en la función conceptual que ambos autores atribuyen a las doctrinas heredadas. Según ha observado Elías Palti, mientras Guerra y Halperín Donghi comparten el rechazo a "la vieja antinomia de la historiografía local entre despotismo hispano y liberalismo latinoamericano", en la visión del primero,

[en el nuevo continente] los patrones coloniales permanecerían inconmovibles a las perturbaciones de orden puramente político traídas por la revolución de independencia. Así, la crítica revisionista se terminará resolviendo en una mera inversión de perspectivas. A la modernidad peninsular ahora se le opondrá el mayor tradicionalismo de las referencias culturales latinoamericanas, preservando en lo esencial el motivo teleológico 'de la tradición a la modernidad' (Palti, 2009, p.21).

En el análisis de Halperín Donghi, por el contrario, el empleo del ancestral lenguaje pactista se dio en el marco de situaciones y en respuesta a interrogantes del todo incongruentes con el orden social en el que ese lenguaje había surgido. Dentro del universo intelectual de autores como Francisco de Vitoria o el jesuita Francisco Suarez, el pacto fundante entre el pueblo y el monarca tenía un origen trascendente, no constituía una libre delegación de la soberanía sino mera trasmisión, y el uno era inconcebible sin el otro puesto que "la asociación política, existente tan solo como relación entre unos que mandan y otros que obedecen, no subsistiría a la caída del poder político, de manera que la república misma habría de morir" (Halperín Donghi, 2009, p.136). En el recuperado pactismo criollo, en cambio, el centro de la reflexión sobre la soberanía se desplazaba del monarca a la nación española y el sistema de gobierno emanaba de una decisión volitiva del pueblo, de su potestad constituyente. Estamos pues en presencia de una mutación sustantiva en el fundamento último de la legitimidad signada por el "tránsito de 
lo religioso a lo político" y del pasado inmemorial - la historia en sentido abstracto - , al flujo y reflujo de la acción humana - la historia en sentido fáctico (Halperín Donghi, 2009, p.149). Así concebido, los retazos del constitucionalismo castellano con los que se edificó el discurso revolucionario estuvo lejos de traducir anhelos de restauración de un pasado idealizado: fue una invención del siglo XVIII. Su exhumación, afirma Halperín Donghi, obedece "a los servicios que ha de rendir como instrumento polémico... contra la monarquía absoluta moderna” y, por las preguntas que se formula, se erige en abierta contradicción con los presupuestos filosóficos que originalmente lo dotaron de sentido (Halperín Donghi, 2009, p.139). Puesto en el lenguaje de la historia conceptual, lo que Halperín Donghi prueba es "cómo nuevos horizontes políticos se desplegarían necesariamente a partir de torciones producidas al interior de los marcos conceptuales e instituciones preexistentes siendo, sin embargo, incompatibles con ellos" (Palti, 2009, p.22). Planteado en términos de la historia cultural, lo que pone de relieve es el "desgaste del significado", ese proceso familiar por el cual "un conjunto de creencias coherentes que daban forma moral al mundo" se alteran y finalmente pierden su sentido "conforme se sobrecargan con otros desarrollos que las incorporan o eclipsan". Persistencia no es en sí misma garantía de significancia, diría Perry Anderson (Anderson, 1994, p.210; 215). Las revoluciones, claro está, son formidables aceleradores de resignificación. ${ }^{2}$

Una similar perspectiva metodológica ha sido adoptada para el análisis del monarquismo popular en las sociedades campesinas. La literatura histórica ha mostrado que el mito del rey benevolente y justo, el llamado monarquismo ingenuo (naive monarquism), es un extendido motivo ideológico de los grupos rurales del Antiguo Régimen en países tan dispares como Francia, Inglaterra, Alemania o Rusia (Field, 1976; Burke, 1978, p.149-177; Perrie, 1995; Scott, 2000; Mamonova, 2016). Según esta

2 En palabras de Halperín Donghi, la etapa revolucionaria genera un "clima de innovación ideológica insólitamente rápida"; "nociones muy nuevas se introducen a cada paso para interpretar una realidad revolucionada", sin que ello reste "de ningún modo prestigio a la recién exhumada tradición medieval” (HALPERÍN DONGHI, 2009, p.136). Un análisis más pormenorizado de la relación entre las perspectivas de Halperín Donghi y Guerra en: SERULNIKOV, 2018. 
concepción, los reyes, emperadores o zares eran por naturaleza ecuánimes y compasivos y los males del mundo - las duras realidades cotidianas de opresión y explotación material - obedecían al despotismo de la nobleza terrateniente, los funcionarios estatales, el clero u otros sectores encumbrados locales. Es un tópico que por mucho tiempo fue visto como un sistema atávico y reaccionario de creencias, orientado a perpetuar el sistema de dominación al insuflar un sentido de inferioridad en las clases subalternas y proveer una válvula de escape a la presión social mediante un desplazamiento del descontento hacia intermediarios y poderosos locales que por principio dejaba a salvo la legitimidad regia. De modo que, si las endémicas protestas campesinas cuestionaban las condiciones de vida rurales, nunca extendían su crítica al orden político que las hacía posibles. Tal conceptualización ha sido revisada en las últimas décadas. Un conjunto de estudios han argumentado que, fuera impuesto desde arriba como medio de control social o constitutivo del repertorio cultural de los sectores subalternos, de sus estructuras de pensamiento, el monarquismo popular fue empleado estratégica y deliberadamente para justificar reivindicaciones de clase que afectaban intereses fundamentales de los sectores propietarios y/o del Estado. En ciertos casos, podían también conducir a impugnar la racionalidad del sistema todo. James C. Scott, en referencia al caso ruso, resumió esta línea de interpretación como sigue:

Tal vez el rasgo más notable del mito era su gran capacidad de transformación a manos de los campesinos creyentes. En primerísimo lugar, se trataba de una invitación a oponerse a cualquier supuesto agente del zar que, al imponer elevados impuestos, la leva, los alquileres, el servicio militar forzado, etcétera, pudiera estar contrariando los deseos del buen zar. Si el zar supiera de los desmanes que sus infieles agentes estaban cometiendo en su nombre, él los castigaría y corregiría la situación. Cuando las peticiones fracasaban y la opresión continuaba, podía significar simplemente que un impostor -un falso zar- estaba en el trono. En ese caso, los campesinos que se unieran a las huestes de un rebelde que se hiciera pasar por el verdadero zar estaban demostrando su lealtad al monarca (Scott, 2000, p.125). 
Parece sensato pensar también aquí en la "paradoja de la innovación" postulada para la cultura política inglesa del siglo XVII, vale decir, acciones colectivas contrarias a las premisas del régimen de gobierno pero predicadas en la negación de lo que al mismo tenían de antagónico. Detrás de la conjura a "los espíritus del pasado" y "la tradición de todas las generaciones muertas", la fidelidad al soberano estaba en las antípodas de una aceptación fatalista del orden establecido. Así mirado, poco de ingenuo queda en pie del monarquismo ingenuo. Cabría en rigor prescindir del adjetivo calificativo y dejar en su lugar solo la referencia sociológica: monarquismo popular.

\section{LA JUSTICIA REGIA Y LOS PUEBLOS INDÍGENAS: HEGEMONÍA Y SEDICIÓN}

Considerar la apelación al rey y a la tradición desde este ángulo resulta a mi juicio de suma utilidad para encuadrar el lugar del monarquismo y la justicia entre los sectores populares americanos durante el período colonial tardío. Es sabido que en el contexto del imperio español existía una íntima ligazón entre la legitimidad monárquica, las normas consuetudinarias y los marcos legales. A diferencia de otras zonas del globo bajo control europeo, o de muchas sociedades europeas de Antiguo Régimen, las relaciones personales de dependencia ocuparon aquí un lugar secundario. La temprana derrota militar de los conquistadores y los encomenderos en México y los Andes abortó para siempre el incipiente proceso de fragmentación señorial de la soberanía y conformación de una nobleza feudal americana. Con las ambiciosas reformas imperiales de mediados del siglo XVI, se establecieron mecanismos centralizados de explotación de la mano de obra nativa conforme a los imperativos materiales metropolitanos, en especial la extracción de metales preciosos, y se construyó un moderno aparato administrativo sin parangón en la Europa de la época. Lo que entonces emergió fue una configuración político-institucional única que combinó antiguas representaciones monárquicas hispanas con los determinantes propios de la sociedad colonial de Indias. 
Por una parte, la Corona se arrogó desde un principio, y lo retomarían con gran denuedo los Borbones en el siglo XVIII, la plena potestad de regular las formas legítimas de ejercicio del poder, el acceso a los recursos económicos y las relaciones sociales. Por otro lado, el orden jurídico conservó su fisonomía tradicional y pluralista. Tradicional porque reconocía a la tradición como derecho, en contraposición con órdenes jurídicos legales que identifican el derecho con la ley y pluralista porque estaba integrado por múltiples conjuntos normativos propios de los cuerpos políticos que componían la monarquía (Garriga, 2010, p.62-63). Cada grupo social o corporación - las ciudades, los gremios de artesanos, las comunidades indígenas, las universidades, los consulados de comercio - contaba con sus propios órganos de gobierno y se consideraba investido de un número de prerrogativas que se derivaban de su antigua sujeción a la Corona. Así pues, las aspiraciones particulares, muchas veces antagónicas entre sí, de distintos grupos sociales tendían a hallar en la tradición, y por tanto el derecho, una inagotable fuente de legitimación. El atributo primordial del gobierno era arbitrar entre estos reclamos. El ejercicio de la justicia conmutativa, dar a cada uno lo suyo, constituía el fundamento mismo del poder. De ahí que no hubiera distinción entre las funciones judiciales y las funciones legislativas o administrativas. Todos quienes ocupaban posiciones de mando eran por definición “jueces”. El Rey, en tanto máximo dispensador de justicia, era el juez supremo, árbitro y garante último del sistema. Pocos conflictos sociales, por más localizados que fueran, no terminaban involucrando el sistema legal y, por añadidura, la voluntad regia.

El aparato judicial y la figura del monarca jugaron entonces un rol nodal en el desarrollo de una política popular contenciosa. Es un fenómeno que, en lo que respecta a las poblaciones indígenas de los Andes y México, ha sido largamente reconocido por la literatura histórica. Su interpretación, empero, varió considerablemente con el paso de los años. Los pioneros estudios aparecidos en las décadas de 1970 y 1980 solían pensar la justicia española como un poderoso instrumento de hegemonía europea sobre los pueblos nativos. Mientras las estrategias legales de las comunidades campesinas les permitían en muchos casos preservar 
sus recursos materiales, sus patrones de organización social y su autonomía política, el empleo de las instituciones coloniales contribuyó en el largo plazo a la formación de una mentalidad de subordinación al orden establecido. Las formidables monografías de William Taylor sobre Oaxaca o de Woodrow Borah sobre el Juzgado General de Indios de Nueva España así lo sugerían. Según sintetizó Steve Stern en su influyente libro sobre el caso peruano, "en la medida que la dependencia de un sistema jurídico se convierte en una estrategia dominante de protección para una clase o un grupo social oprimidos, puede socavar la posibilidad de organizar un ataque más ambicioso encaminado a derrocar la estructura explotadora en sí. Cuando ocurre esto, un sistema de justicia que funcione contribuye a la hegemonía de una clase dominante" (Stern, 1986, p.218; Taylor, 1985, p.151-157). Ciertamente, para dirimir sus diferencias con las elites locales, las comunidades rurales a menudo recurrieron asimismo a la revuelta. No obstante, los objetivos de estos alzamientos no fueron impugnar el sistema de dominación colonial en sí mismo, sino protestar contra funcionarios particularmente abusivos, nuevos impuestos o avances sobre los sistemas comunales de autoridad. $\mathrm{Al}$ igual que con las demandas judiciales, los funcionarios españoles tendieron menos a reprimir indiscriminadamente las protestas, que a buscar un acuerdo que permitiera volver a la rutina previa. Aunque el resultado final varió de caso a caso, el Estado pareció crear así cierto sentido de justicia (Borah, 1983; Taylor, 1979; Katz, 1990; Walker, 1999).

La función del imaginario y las instituciones de justicia españolas en la reproducción del régimen colonial se reflejó, por oposición, en la naturaleza de las grandes rebeliones indígenas. En contraposición con las protestas legales, las sublevaciones opusieron a los procedimientos judiciales que regulaban los conflictos sociales, formas sistemáticas de violencia colectiva. El recurso a la fuerza guarda una relación de exterioridad con respecto al derecho y su irrupción está vinculada al fracaso de estrategias jurídicas. El surgimiento de manifestaciones masivas y organizadas de violencia remite a su vez a la propagación de fines antagónicos a la dominación española. A diferencia de los limitados objetivos perseguidos por las revueltas locales, muchas veces absorbidos de hecho 
o derecho por el Estado, las insurrecciones adoptaron por definición la forma de "conspiraciones con fines revolucionarios explícitos", guerras étnico-raciales orientadas a poner fin a los gobernantes y población europea (Coatsworth, 1990, p.30-48). En los Andes, la emergencia de movimientos insurgentes fue atribuida a la propagación de concepciones milenaristas y mesiánicas, un sistema esencialmente autónomo de creencias culturales que entrelazaba los anhelos de cambio político con una imagen idealizada del pasado prehispánico, vale decir, con una utopía neo-Incaica, una utopía andina. Los grandes alzamientos rurales, en resumen, aparecen como la expresión de identidades sociales construidas al margen de la ideología colonial y su naturaleza es considerada de un orden radicalmente diferente al de las formas rutinarias de interacción entre las comunidades nativas y los grupos dominantes.

Una postura semejante ha sido asumida más recientemente por Eric Van Young en su penetrante investigación de las rebeliones campesinas mexicanas encabezadas por los padres Miguel de Hidalgo y José María Morelos en la década de 1810. Argumenta que la movilización de masas fue motivada o bien por expectativas mesiánicas vinculadas a un putativo "Estado indígena en las sombras" (una suerte de nacionalismo neo-Azteca), o bien por concepciones de monarquismo ingenuo basadas en imágenes mistificadas de Fernando VII o incluso del propio líder criollo rebelde Ignacio Allende. No es de extrañar, por ende, que afloren frecuentes paralelismos con el movimiento de Túpac Amaru según la visión que trasuntaban los estudios de los años ochenta, como el de Alberto Flores Galindo, Buscando un Inca. Identidad y Utopía en los Andes, o Jan Szeminski, La utopía tupamarista). No sorprende tampoco que las expectativas mesiánicas y el mito del buen rey operen en oposición complementaria a la inveterada doctrina que, según el autor, impregnaba las prácticas políticas campesinas de la época: una cosmovisión localocéntrica, o "campanillismo", consistente en "la tendencia de los campesinos a ver los horizontes sociales (y políticos) como algo que se extendía únicamente hasta donde podía observarse desde el campanario de la iglesia del pueblo" (Van Young, 2006, p.847). Es una dicotomía que nos recuerda lo afirmado por Eric Hobsbawm sobre la acción 
política campesina en general, la cual tendría lugar solo en el "vientre de la parroquia”, el microcosmos aldeano, o "(conceptualmente) la raza humana o el universo" (Hobsbawn, 1973, p.8). Poco o nada ocurre en el medio. Por cierto, Van Young no encuentra evidencias convincentes del surgimiento, incluso en una coyuntura de tan extraordinaria conflagración social y frontal oposición al gobierno español, de sentimientos de identidad colectiva campesina, de pertenencia a un incipiente nacionalismo o patriotismo mexicano, o al menos de genuina preocupación por cuestiones de Estado que excediesen la escala puramente aldeana.

A mi parecer, en las últimas dos décadas, aproximadamente, la historiografía ha ofrecido una imagen alternativa de la relación entre monarquismo popular, derecho y legitimidad política, y por consiguiente de las bases ideológicas de la acción colectiva indígena. En primer lugar, resulta preciso desacoplar legalidad y hegemonía. El recurso a los tribunales coloniales y al discurso jurídico no dotaba necesariamente a las instituciones estatales de legitimidad. Muy por el contario, bajo ciertas condiciones, podía funcionar como un eficaz modo de sacar a la superficie las inherentes contradicciones entre las premisas ideológicas del dominio español, su diseño jurídico, y las relaciones de poder existentes. En la medida que esas contradicciones no eran derivativas y aleatorias sino generalizadas y sistemáticas, ahondar en las mismas podía poner en cuestión la estructura misma de gobierno. En este sentido, es preciso no perder de vista que las políticas judiciales indígenas tenían mucho menos que ver con cuestiones de legislación y criminalidad que con cuestiones de justicia y derechos. Y puesto que los pleitos involucraban instituciones tan fundamentales como los gravámenes de la Corona, la Iglesia y las elites rurales, el gobierno comunal, los derechos de propiedad de la tierra o las prácticas religiosas, y puesto que los motivos de descontento afectaban en mayor o menor medida al conjunto de la población indígena, los litigios tendían a convertirse en agentes de politización de las relaciones sociales y de universalización de las demandas. Es un fenómeno que guarda cierta afinidad con lo postulado por Roger Chartier respecto de "la politización de la cultura popular" del campesinado y el artesanado francés en el siglo XVIII, conforme 
las instituciones estatales y las concepciones normativas absolutistas fueron avanzando sobre las antiguas jurisdicciones señoriales y gremios de oficios (Chartier, 1995, p.153). Apuntemos también que dado que los grupos de poder locales concebían la apelación a la justicia como un inequívoco signo de insubordinación y los procedimientos judiciales hacían recaer en los propios litigantes la responsabilidad de forzar la implementación efectiva de las sentencias, las estrategias legales nunca presuponían, y pocas veces comportaban, la resolución pacífica de los conflictos sociales. Por el contrario, representaban el inicio de enfrentamientos frontales y abiertos, o al menos su continuación por otros medios (MacLachlan, 1988; Serulnikov, 2006; Owensby, 2008).

En el fondo, como hemos dicho, el único modo de discernir el significado concreto de las expresiones de apego a los procedimientos judiciales y de ferviente devoción al monarca, es situar esas reivindicaciones en la trama de circunstancias que las rodearon, en sus contextos específicos de producción y reconocimiento. Ello resulta particularmente evidente cuando se observan las características del discurso político subalterno durante la crisis del imperio español. Así, por ejemplo, el estudio de Cecilia Méndez sobre los pueblos campesinos de Huanta, en la sierra peruana, revela que la fidelidad a la Corona y el consiguiente repudio a los proyectos emancipadores criollos - la evocación de ideas perfectamente tradicionales - sirvió como vehículo de vastas agendas de transformación social, como medio de legitimar la instauración de un orden perfectamente sedicioso (Méndez, 2014). Marcela Echeverri, por su parte, demuestra el potencial subversivo del monarquismo popular entre las comunidades indígenas y los esclavos de Colombia durante las guerras de la independencia. Reivindicaciones fundamentales a la sociedad colonial como el tributo y las formas de trabajo forzoso indígena, el autogobierno comunal, la igualdad legal y la abolición del esclavismo fueron proclamadas en nombre del rey. Igualmente significativo, el regalismo no obedeció a imágenes mistificadas del monarca como una suerte de mesías, sino a decisiones pragmáticas vinculadas a la oportunidad de reformar las estructuras sociales dentro de los marcos del régimen político vigente. Una vez más, nada de ingenuo, o mistificado, entrañaba esa clase de monarquismo (Echeverri, 2016). 
Cabría postular, en síntesis, que en el mundo hispanoamericano el rey era un significante vacío. El concepto del monarca benevolente no conllevaba una visión pre ordenada del mundo, imbuida de fatalismo, conservadora y tradicionalista, sino que abrigaba visiones muy dispares y, en ocasiones, antagónicas entre sí. En la medida que funcionaba como un principio altamente genérico de unidad en la diversidad y orden en el conflicto, en la medida que no estaba expuesto al roce y desgaste cotidiano de magistrados y tribunales, su imagen podía ser empleada a efectos de cuestionar radicalmente las relaciones de poder y las jerarquías sociales sobre las que el dominio imperial se erigía. De allí, como se dijo al comienzo, que las implicancias profundas del legitimismo monárquico no puedan ser deducidas exclusivamente de las proclamaciones formales y las abstracciones ideológicas en las que aparece envuelto, sino de la dinámica e inscripción pública de las acciones colectivas. Una vez reconocido ello, no aparece como contradictorio, por ejemplo, que en la provincia colombiana de Popayán los esclavos hubieran abrazado la causa realista como un medio de alcanzar su liberación, mientras en Cartagena lo hicieran sumándose al bando patriota, según ha mostrado Marixa Lasso (Lasso, 2013). Tampoco que los Iquichanos de Huanta, tras haber apoyado a la Corona en las guerras independentistas, enarbolaran luego nociones de ciudadanía y patriotismo que, a semejanza de lo sucedido con su previa profesión de fe realista, se alzaban en abierta oposición al régimen político fundado en esos conceptos.

\section{MONARQUISMO POPULAR Y LEGALIDAD}

\section{EN LOS LEVANTAMIENTOS TUPAMARISTAS Y KATARISTAS}

La dinámica ideológica de la sublevación encabezada por Túpac Amaru ilustra vívidamente las ambivalencias del monarquismo popular. Es bien conocido que la rebelión panandina terminó gravitando en torno a la creencia, o el anhelo, de que Túpac Amaru se convertiría en un nuevo Inca rey. Es materia de debate que el líder cuzqueño hubiera sido percibido como un personaje de rasgos mesiánicos (la reencarnación del último Inca) y el levantamiento como un movimiento milenarista (el 
fruto de un pachacuti, un cataclismo cósmico). Pero resulta innegable que, entre 1780 y 1782, las masas indígenas llegaron a ver la restauración del Incario como una opción efectiva. Ahora bien, que Túpac Amaru se hubiera erigido a los ojos de sus seguidores indígenas en una alternativa al colonialismo español, no resultó incompatible con el empleo del lenguaje monárquico, con que tradujese sus ambiciones políticas en términos del antiguo constitucionalismo hispano, la equilibrada relación entre el monarca y los reinos y comunidades que componían el imperio. Empezando con el evento que puso en marcha el ciclo revolucionario, el ajusticiamiento público del corregidor Antonio de Arriaga en el pueblo de Tinta, el líder cuzqueño proclamó que en su lucha contra los gobernantes abusivos y la explotación indígena seguía estrictas órdenes de Carlos III. No era en perjuicio sino en beneficio de los derechos del soberano que se había alzado, aseguró una y otra vez. Todavía dos semanas antes de ser capturado, habiendo enumerado en una misiva a José Antonio de Areche - el Visitador General del Perú por entonces en el Cusco al frente de un poderoso ejército - la larga lista de agravios que lo habían impulsado a levantarse (los repartimientos de mercancías, la mita minera, las alcabalas, las condiciones de vida de los peones de las haciendas y los obrajes, las exorbitantes cargas parroquiales, la corrupción de la justicia), recalcó que si estas quejas nunca habían sido atendidas, no habría sido por culpa del Rey: "será la causa porque no han llegado a los reales oídos; porque es imposible que tanto llanto, lágrimas y penalidades de sus pobres e infelices provincianos de todos estados dejen de enternecer ese corazón compasivo y noble pecho del Rey mi Señor" (citado en Lewin, 1957, p.474). Estas declamaciones de lealtad al monarca, por otra parte, se conjugaron con un programa de transformaciones económicas que interpelaron a vastos segmentos de la población local. En su repudio al centralismo borbónico, Túpac Amaru articuló formas de legitimismo monárquico comparables a previas conspiraciones criollas en el Perú o a la contemporánea "revolución de los comuneros" de Nueva Granada. La sofocante presión fiscal, la erección de monopolios estatales sobre productos de consumo masivo, la disrupción de los tradicionales circuitos mercantiles que conectaban la sierra 
peruana con el centro minero potosino y la sistemática discriminación de los criollos de las altas magistraturas, en suma, el afán de los Borbones por tornar las posesiones de ultramar en dominios coloniales plenos, ofreció a múltiples sectores de la sociedad americana una fuente común de resentimiento y, por un muy breve lapso al menos, la ilusión de objetivos compartidos. El involucramiento en la rebelión de ciertos grupos hispánicos y la fuerte impronta de sus reclamos condujo a que numerosos historiadores lo calificasen como un movimiento multiétnico, protonacional, no estrictamente indígena. ${ }^{3}$

A mi juicio, sin embargo, el monarquismo y los afanes reformistas de Túpac Amaru y algunos de sus colaboradores no debieran ocluir la dinámica ideológica profunda del fenómeno insurreccional. Si bien las ideas pudieron haber tenido raíces comunes, el significado que asumieron en la práctica fue por completo diferente. En el contexto de un movimiento indígena de masas, encabezado por un miembro de la nobleza nativa, las ideas esgrimidas por Túpac Amaru, por genuinamente monárquicas y moderadas que fueran o parecieran, sirvieron como vehículo de prácticas políticas que minaron el principio fundante del colonialismo en su dimensión étnico-cultural: la noción de que existía un definido vínculo entre poder y cultura, que el dominio político se basaba en la inherente superioridad de la civilización europea. Ello llevó a su vez a que el contenido concreto del programa insurgente fuera inestable y, en última instancia, irrelevante. La asombrosa fluidez con la cual Túpac Amaru pasó de ideas de legitimismo monárquico a nociones de un nacionalismo peruano o a promesas de restitución incaica ha sido una fuente inagotable de debates políticos y académicos. Pero al menos en lo que atañe a los grupos hispánicos, especialmente aquellos más proclives a simpatizar con el levantamiento, todo ello terminó careciendo de importancia. Como los criollos aprenderían rápido, y sus descendientes en el siglo XIX no lo olvidarían, la movilización autónoma del campesinado andino y el encumbramiento de uno de sus líderes como autoridad

3 Distintas caracterizaciones del movimientos en función de su composición social y liderazgo en FISHER, 1976; O’PHELAN, 1988; GARRETT, 2005; CAHILL, 2008. 
suprema eran incompatibles con la perpetuación de las relaciones de subordinación colonial cualquiera fuera el régimen político formal que las enmarcase. Una vez desmanteladas las jerarquías coloniales, una vez que las relaciones entre indios y no-indios debían ser establecidas bajo nuevos principios, toda consideración sobre los proyectos políticos y aspiraciones económicas puntuales era superflua.

Es lo que trasunta la más minuciosa investigación sobre el movimiento con que contamos hoy, La rebelión de Túpac Amaru de Charles Walker. Mientras algunos criollos se sumaron al alzamiento y unos pocos alcanzaron posiciones de liderazgo, su participación fue en conjunto escasa en términos cuantitativos e idiosincrática en sus móviles. Muchos tenían estrechos lazos personales previos con Túpac Amaru y otros habían sido tomados prisioneros durante las primeras semanas y fueron luego persuadidos o forzados a colaborar. Sería erróneo, en cualquier caso, considerarlos representativos de voluntades generales, de los criollos en tanto sector social, tal como sí ocurrió con las contemporáneas "revolución de los comuneros" de Nueva Granada o la sublevación de la villa minera de Oruro (Phelan, 1978; Cajías de la Vega, 2004). De hecho, salvo algunos casos puntuales, el propio Túpac Amaru nunca confió en sus aliados, y tuvo buenos motivos para no hacerlo: la mayoría se pasó de bando antes o durante el asedio a la ciudad de Cuzco en diciembre de 1780, la principal iniciativa militar de las fuerzas insurgente en esta área. Las muy citadas imputaciones judiciales a criollos y miembros del clero por presunto involucramiento en la rebelión refleja, según el autor, la "paranoica interpretación" del evento por parte de los altos magistrados coloniales. Pese a la retórica de los magistrados regios, "dichos grupos permanecieron leales a la Corona salvo excepciones aisladas" (Walker, 2015, p.335-336).

Si el monarquismo popular no puede ser mecánicamente tipificado por la inherente estrechez de sus horizontes ideológicos, por su conservadurismo fatalista, lo mismo cabe para las prácticas judiciales. Es lo que sugiere lo acaecido en otro de los grandes núcleos de actividad insurgente durante la rebelión general de 1780-1782: el norte de Potosí. Como he desarrollado en mi libro sobre el tema (Serulnikov, 2006), el alzamiento de los indígenas de la provincia de Chayanta liderado 
por Tomás Katari revela que el desarrollo de masivos y comprensivos desafíos al orden establecido podía no solo expresarse en el lenguaje del legitimismo monárquico sino estar íntimamente imbricado con las formas cotidianas de negociación y conflicto entre los pueblos andinos y los grupos de poder coloniales. La más extendida y sangrienta sublevación en la historia de la región no se derivó en modo alguno de "una conspiración con objetivos revolucionarios explícitos". Miradas de cerca, las reivindicaciones descuellan por su moderación más que por su radicalismo. Como tantos otros pueblos andinos de la época, las comunidades norpotosinas denunciaron la ilegitimidad política y las prácticas económicas de sus caciques, los abusos de poder de los corregidores y sus repartimientos de mercancías, las extravagantes contribuciones parroquiales o la escasez relativa de tierras. Y como tantos otros, llevaron una y otra vez sus reclamos ante diversos tribunales coloniales, incluyendo en este caso la flamante corte virreinal de Buenos Aires creada en 1776; tras el estallido de la rebelión, despacharon asimismo largas representaciones al propio monarca. Son patrones de protesta que, lejos de preanunciar un masivo alzamiento en armas, nos recuerdan del duradero impacto de la justicia española, de las rutinas de petición, en la consciencia indígena. Del mismo modo, las comunidades probaron a cada paso su voluntad de discernir entre cargas económicas lícitas e ilícitas: mientras aborrecieron las demandas materiales de corregidores, caciques y curas, nunca dejaron de satisfacer puntualmente, tanto antes como durante la rebelión, sus dos obligaciones esenciales a la Corona los tributos y la mita potosina. No es de extrañar entonces que el virrey del Río la Plata Juan José de Vértiz, entre otros magistrados, hubiera estado convencido que de haberse atendido a tiempo los reclamos, como era menester, el movimiento jamás se hubiera propagado por el resto de la región, ni llegado a los extremos de violencia que alcanzó, incluso previo al estallido del alzamiento tupamarista en el Cuzco.

¿Significa todo ello que los alcances ideológicos de la movilización popular hubieran sido en definitiva acotados y meramente reactivos? ¿Se trató de una mera protesta reivindicativa salida de cauce? Por el contrario, los denodados procesos de apelación judicial a las más altas 
magistraturas regias, la adopción de rituales europeos de justicia y la satisfacción de sus obligaciones económicas al rey, antes que inhibir legitimaron generalizados ataques a las pluriseculares estructuras coloniales de poder en el mundo rural. No afianzaron la hegemonía de las clases gobernantes sino que hicieron posible que los pueblos andinos se erigieran en actores políticos capaces de poner en disputa las formas apropiadas de ejercicio de la autoridad regia, eclesiástica y étnica. El movimiento se tornó profundamente sedicioso no por su repudio a los marcos legales existentes, como sus enemigos proclamaron, sino en virtud de los mismos actos que las comunidades consideraban probaban su lealtad a la Corona. Cierto es que el monaquismo de los pueblos norpotosinos habría abrevado de una arraigada concepción andina sobre las relaciones ideales entre las comunidades y el Estado que antecedieron y sucedieron al dominio español. Tristan Platt la definió como un "pacto de reciprocidad": a cambio de cumplir con sus obligaciones primarias a la Corona (el tributo y la mita), los indígenas esperaban que se resguardasen sus ancestrales derechos colectivos al autogobierno y al pleno usufructo de sus tierras. Pero cualquiera fueran las ideas que informaron la proclamada lealtad al Rey, es claro que las utopías nativistas, los programas revolucionarios y las identidades binarias no fueron aquí el origen de la lucha ni su impulso primario. La radicalización de la conciencia política insurgente emanó de la articulación de las batallas discursivas en los tribunales coloniales y las batallas armadas en las aldeas rurales (Platt, 1982).

No son por cierto circunstancias únicas al sistema colonial español. Resulta por demás sugerente que fenómenos similares se registren en el mundo rural europeo de la época. Así, un estudio de David M. Luebke sobre el monarquismo popular en la región de la Selva Negra en Alemania durante el siglo XVIII, muestra que las frecuentes delegaciones campesinas despachadas a la corte imperial de Viena para elevar en persona sus reclamos sociales a los reyes Habsburgos estaban lejos de encarnar una "ideología hegemónica" que vedaba expectativas de cambios radicales, aun revolucionarias. Detrás de la "incondicional confianza de los campesinos en la benevolencia de los soberanos combinada con 
una casi idólatra obsesión con los 'derechos antiguos", yacían, nos dice, tres presupuestos constitutivos de las concepciones políticas populares de la Europa moderna: "la naturaleza recíproca, exclusiva y contractual del gobierno” (Luebke, 1997, p.75; 82). En una conclusión de nítidas resonancias para los Andes coloniales, afirma que,

En tanto reflejo de las creencias populares acerca de las relaciones ideales entre los reyes y las corporaciones de individuos, el monarquismo campesino estaba fundado sobre la presunción de obligaciones mutuas tan asimétricas y estrictamente definidas que ninguna condición de la vida real podía satisfacer sus requisitos. En la medida que la experiencia cotidiana refutaba tal reciprocidad a prácticamente cada paso, el monarquismo justificaba la resistencia contra virtualmente todas las autoridades no-campesinas, incluido el emperador mismo si los hechos probaban que se había rehusado a cumplir con su parte del trato. El monarquismo, en síntesis, equivalía a una comprensiva defensa en contra de la dominación, incluyendo la de naturaleza jurídica. En verdad, no tenía mucho sentido excepto como una ideología contenciosa (Luebke, 1997, p.75).

Tratándose de un contexto colonial, en el caso que nos ocupa habría que añadir una dimensión étnico-cultural al argumento socio-político. El proceso por el cual los pueblos norpotosinos se apropiaron de la potestad de dictar el funcionamiento debido de las instituciones españolas terminó desplazando su lugar en el orden natural de las cosas: el uso de la diferencia cultural como significante de inferioridad racial y el empleo de la noción de inferioridad racial para reivindicar el derecho de dominación política. En este sentido, la identidad de las comunidades andinas no se construyó sobre la negación de la idea de civitas impuesta por la dominación europea sino más bien sobre su resignificación. En la medida que este concepto de humanidad se fundaba en su reconocimiento de las instituciones de justicia y el cumplimiento de sus cargas económicas como vasallos del Rey, era en el mejor interés de los poderes locales el inscribir las prácticas indígenas como una reversión al 
estadío de civilización barbárico e idólatra propio del pasado prehispánico, reditar el discurso de la conquista. Como bien ilustra la siguiente aserción de un corregidor de Chayanta, la única meta de los insurrectos era "vivir sin sujeción alguna a que por naturaleza son tan propensos (...) solicitando con el mayor esfuerzo eximirse de la observancia de las leyes divinas y humanas y negándose protervos a la exención de las resoluciones de la Real Justicia y obediencia debida a nuestro Soberano". ${ }^{4}$ Lo que aquí aparece en juego es el núcleo ideológico primario del colonialismo occidental, un mecanismo de reproducción de la diferencia étnica que Partha Chatterjee denomina the rule of colonial difference: "un moderno régimen de poder destinado a nunca consumar su misión normalizadora puesto que la premisa de su poder es la preservación de la alteridad de los grupos dominantes" (Chatterjee, 1993, p.18). Al ahondar en las contradicciones entre derechos jurídicos y justicia colonial, entre legalidad y poder, y al conjurar la figura del monarca como principio ordenador y justiciero y corroborar con acciones concretas tal lealtad, las prácticas políticas insurgentes terminaron por subvertir la experiencia histórica de subjetivación colonial: la función de la población hispana como agentes legítimos del dominio español, la violencia colectiva de los nativos como un síntoma de salvajismo inscripto en su historia y su naturaleza, la justificación del colonialismo europeo como una misión civilizatoria sin fin.

\section{EL REGALISMO Y LA EMERGENCIA DE UNA CULTURA POLÍTICA URBANA CONTESTATARIA}

El monarquismo popular adquiere un sentido muy diferente cuando desplazamos la mirada hacia otro escenario: la cultura política urbana. En los últimos años he investigado los cambios en la vida pública de la ciudad de La Plata - sede de la real audiencia de Charcas, el arzobispado y la Universidad de San Francisco Xavier - durante las décadas de 1770 y 1780. Como otras ciudades andinas de la época, La Plata fue

4 Archivo General de la Nación (AGN), Sala IX, Interior, legajo 10, expediente 1, f. 141. 
el blanco de una serie de medidas asociadas al centralismo borbónico que trastocaron muy arraigados balances de poder. En el curso de solo dos años se renovó por completo el plantel de ministros de la audiencia con letrados españoles, lo mismo que la mayoría de los corregimientos y otras altas magistraturas; se produjeron serios avances sobre la jurisdicción y las preeminencias ceremoniales del ayuntamiento; se estableció un monopolio regio sobre un producto de amplio consumo popular como el tabaco, que provocó alzas en su precio de venta; y se fijó por primera vez una guarnición permanente de soldados peninsulares que fue acompañada por la desmovilización de la compañía de milicias locales levantadas en 1780 con motivo de la guerra contra los insurgentes indígenas. Las reformas coincidieron con una excepcional coyuntura a escala regional signada por el estallido de motines antifiscales en las principales urbes andinas (Arequipa, La Paz, Cochabamba, Cuzco) y, desde luego, los grandes levantamientos tupamaristas y kataristas.

En este contexto, se iban a generar continuos procesos de confrontación del vecindario, tanto patricios como plebeyos, con los magistrados regios de Charcas y la corte virreinal de Buenos Aires. El resultado neto fue un inédito clima de agitación política que auspició propició la multiplicación de debates y controversias en distintos espacios (los estrados judiciales, la sala del ayuntamiento, la Universidad de Charcas y las tertulias privadas, las calles y plazas de La Plata); la propagación de pasquines y décimas anónimas como medio de circulación de opiniones contestatarias; la construcción de la ciudad como sujeto histórico y político en el campo del ceremonial; la realización de cabildos abiertos en los que se discutieron e impugnaron las providencia de los tribunales superiores, incluyendo las del virrey del Río de la Plata; y la elección por parte del claustro universitario de un rector en franca oposición al arzobispo y otros altos dignatarios civiles y eclesiásticos. El más estruendoso producto del clima de conflictividad imperante fue el estallido, en 1782 y 1785, de dos violentos ataques a la guarnición militar, las primeras revueltas populares en la historia de esta urbe. Precipitados por la muerte de paisanos a manos de soldados, los motines sacaron a la luz los conflictos de poder y prestigio entre el ejército regular y las milicias urbanas 
que habían hecho frente al asedio indígena, las afrentas cotidianas de la tropa al honor y masculinidad de la población local y la impunidad de que gozaban por sus fueros especiales. Aunque protagonizadas por los miembros de los gremios de artesanos y las castas en general, los motines contaron con el resuelto apoyo de la aristocracia urbana, la "gente de razón", cuyas opiniones fueron asumidas institucionalmente por el ayuntamiento (Serulnikov, 2009; 2017).

Cuando observamos todo el arco de prácticas y discursos, se advierte la existencia de una sostenida reflexión crítica en torno al estatuto de la república, del cuerpo político de la ciudad, en el marco de la monarquía. Vale decir, el desarrollo de una esfera política pública o, para evitar confusiones con fenómenos propios de la sociedad burguesa europea del siglo XIX, de diversos dominios de la vida pública en los que se discuten asuntos de interés común por fuera de del control y supervisión de las autoridades regias y eclesiásticas. Es un patrón colectivo de comportamiento que iba en sentido opuesto al mantra del renovado discurso regalista español del siglo XVIII: "reglas fijas y obediencia a la ley sin interpretación” (Taylor 1996, p.13; Paquette, 2008, p.70-92). Una prédica elocuentemente articulada por el virrey de México, el marqués de Croix en 1767, cuando sentenció que "de una vez para lo venidero deben saber los súbditos del gran monarca que ocupa el trono de España, que nacieron para callar y obedecer y no para discurrir, ni opinar en los altos asuntos del gobierno".5 Dos décadas más tarde, el virrey del Río de la Plata, el marqués de Loreto, lo puso de manera más sucinta aún. Frente a los constantes planteamientos y protestas de los vecinos de La Plata, le ordenó a un nuevo Intendente de Charcas que desechase de plano cualquier tipo de reclamo: "No está el gobierno para complacer a esta especie de gentes", le recordó. ${ }^{6}$ Una visión del orden social en la que el disenso no tenía lugar y, cuando afloraba, solo podía hacerlo como objeto de escarnio.

\footnotetext{
5 Bando del marqués de Croix, México, 25 ago. 1767. En: http://www.memoriapoliticademexico. org/Textos/1Independencia/1767BMC.html.

6 AGN, IX, Interior, legajo 22, expediente 4.
} 
Ahora bien, a los fines de una discusión sobre los sentidos del monarquismo popular, habría que subrayar que fueron las sobresalientes credenciales realistas de la ciudad, en particular el rol de la población urbana en la lucha contra los rebeldes tupamaristas, las que paradójicamente terminaron por galvanizar la oposición pública a las políticas imperiales. Hay que recordar que a diferencia de otras áreas andinas, en La Plata el levantamiento indígena no fue derrotado por ejércitos regulares provenientes de Lima o Buenos Aires sino por las milicias urbanas organizadas en compañías de patricios y plebeyos. Fueron los vecinos los que cargaron con el esfuerzo bélico, especialmente durante el asedio a la ciudad por parte de miles de campesinos de varias provincias en febrero de 1781. Por otra parte, La Plata había estado exenta de la agitación social contra el incremento de los impuestos que conmovió buena parte de las ciudades peruanas de la época. Su lealtad motivó que el influyente fiscal de la audiencia, y futuro primer Intendente de Potosí, Juan del Pino Manrique, comparara "la fidelidad de los Chuquisaqueños con la de los Castellanos", puesto que si los Borbones debían a los últimos "la firmeza del trono de España", debían a los primeros la conservación del reino del Perú "por oponerse a las sediciones y odiar la dominación del rebelde Tupac-Amaro". Combinando en una misma frase los motines urbanos antifiscales y los levantamientos tupamaristas, observó que,

Cuando Arequipa, La Paz, Oruro y Cochabamba veían en sus calles y Plazas el tumulto, la conjuración de unos contra otros, las muertes, los robos y los derechos del rey atropellados (...) entonces era invariable esta ciudad [de La Plata] en su amor al Rey, en el vasallaje en defensa de sus Regalías y en cuantas preciosas cualidades constituyen el glorioso timbre de fidelidad según toda su extensión.?

7 Juan del Pino Manrique al Virrey Juan José de Vértiz, 18 nov. 1781, Archivo General de Indias (AGI), Charcas 595. 
Lo que Pino Manrique no pareció sospechar fueron las paradójicas consecuencias de esta fidelidad. La inaudita contención política que sin solución de continuidad se desencadenaría durante el siguiente lustro muestra que la guerra contra los insurgentes indígenas sirvió para reafirmar los derechos de la ciudad en oposición al absolutismo borbónico. Habilitó ampulosas manifestaciones de monarquismo popular que a la par que escenificaron la inconmovible lealtad a Carlos III (el "invariable amor al Rey", "el vasallaje en defensa de sus Regalías", en palabras de la época), se erigieron contra todo lo que las políticas y la concepción monárquica de Carlos III representaba. La victoria contra las fuerzas rebeldes fue percibida por los moradores como una "reconquista del reino", y la reconquista, como la conquista dos siglos y medio atrás, debía ser portadora de privilegios y preeminencias.

Es equivocado, no obstante, considerar el monarquismo como una reacción conservadora frente a las tentativas de implantación del modelo absolutista, como una "nostalgia de las antiguas instituciones representativas", una búsqueda de amparo en "las viejas libertades" (Guerra, 1992, p.28). Lo es por dos motivos. Por un lado, porque las contiendas políticas de la época llevaron a que el ayuntamiento se tornase una caja de resonancia de antagonismos que excedían largamente los asuntos propiamente corporativos, que dejase de operar como una mera institución administrativa municipal, monopolizada por un grupo de familias notables, en relación más o menos simbiótica con las magistraturas regias, y empezase a servir como órgano de representación política del vecindario, en abierta oposición a las principales instancias de poder español. Y que los sectores sociales a los que proclamó representar abarcaran, de manera muy conspicua y activa, no sólo las elites sino también la plebe urbana, especialmente los miembros de los gremios de oficios. De modo que la consuetudinaria división binaria de la sociedad hidalga de Indias entre españoles peninsulares y españoles americanos, de una parte, y sectores plebeyos, de otra, comenzó a mostrar signos de resquebrajamiento. Se diría que la política de la plaza, las tertulias y las calles va ir encontrando su lugar también en la sala capitular, y en la sala capitular se discutirán asuntos que hasta entonces era privativos 
a los magistrados del rey. En el proceso, se atribuyeron aquel derecho que el marqués de Croix creía vetado por definición a los súbditos del rey: el discurrir y opinar "en los altos asuntos del gobierno". No en vano, uno de los varios cabildos abiertos convocados por el ayuntamiento durante estos años fue tildado de "un crimen horrendo de sedición por haberse osado a exponer importantes cuestiones de Estado a la censura de un Pueblo rudo e ignorante". Parafraseando lo sostenido sobre las peticiones al Rey durante la Revolución Inglesa del siglo XVII: actos de subversión arropados en el leguaje del derecho y la tradición.

La apelación de la ciudad a los servicios pasados y presentes al monarca tampoco representa una reacción tradicionalista porque, mirado desde la óptica de la población local, la concentración del poder en manos de la administración regia significó antes que nada una concentración del poder en manos del centro metropolitano y sus agentes en América, reafirmó su lugar subordinado en el marco del imperio. En otras palabras, la orientación absolutista de los Borbones adquirió distintivas resonancias en sus posesiones de ultramar, no fueron las mismas que en España. La cuestión de cómo se gobernaba, el sistema político-institucional, aparecía indisolublemente ligada a quiénes lo hacían y en virtud de qué intereses, la distribución geopolítica del poder. Cabe decir aquí lo que tan agudamente Emilia Viotti da Costa dijo del imperio portugués: "las críticas que en Europa el pensamiento ilustrado dirige al absolutismo, adquieren en el Brasil el sentido de críticas al sistema colonial" (citado en Halperin Donghi, 1985, p.102). Ello explica también que uno de los efectos acumulativos de los continuos enfrentamientos entre vecinos y magistrados fuera el poner en tensión la pertenencia de las elites criollas, o mejor dicho de los sectores patricios, avecindados, a la putativa nación universal hispánica, si bien no ciertamente en términos étnico-culturales (como lo fue con los antagonismos desatados por los levantamientos tupamaristas y kataristas), sí en tanto comunidad de derechos. Si, como apunta Octavio Paz, "toda sociedad al definirse a sí misma, define a las otras. Y esta definición asume casi

8 Francisco Cano de La Puerta al Virrey Marqués de Loreto, 15 oct. 1785, AGI, Buenos Aires 72. 
siempre la forma de una condenación", las identidades colectivas articuladas detrás de esta versión del monarquismo popular expresaban un doble proceso de condenación: el de la alteridad radical de la población indígena suscitada por la revolución tupamarista y el de la colonialidad de las estructuras de gobierno suscitada por las políticas borbónicas (Paz, 1995, p.47).

Las paradojas del legitimismo monárquico se advierten en un dominio de la vida pública más opaco, precisado de decodificación, pero no menos significativo que las protestas colectivas: el ceremonial. La vindicación de los percibidos derechos del vecindario en el seno de la monarquía se canalizó mediante la apelación a una figura de poderoso simbolismo político: la ciudad como sujeto histórico, portadora de una identidad común y privilegios inalienables. Es un estatuto que aparece dramatizado con particular brillo en una ceremonia pública en honor de Carlos III el 4 de noviembre de 1781. Aclaremos primero que en el curso del siglo XVIII las festividades experimentaron importantes mutaciones tanto en los modos de representación del Rey como en el rol de las ciudades y sus elites gobernantes. Así, según ha mostrado Linda A. Curcio-Nagy, el ayuntamiento de México fue gradualmente perdiendo su acostumbrado control sobre la organización y contenido de las fiestas a manos de los funcionarios regios. Las autoridades concejiles debieron incluso renunciar a su potestad sobre el principal símbolo de la ciudad y objeto de devoción popular, la Virgen de los Remedios: declarada santa patrona de la Corona española, se prohibió el uso de su imagen para las procesiones organizadas por el cabildo (Curcio-Nagy, 2004). Para el caso de Lima, Alejandra Osorio ha notado que las referencias a las comunidades políticas que integraban la monarquía hispánica, tales como el "Reino del Perú", cedieron lugar en las celebraciones por el natalicio, coronación o exequias de los monarcas a genéricas menciones a "las Indias". Lo propio ocurrió con los retratos de los reyes, que fueron sustituidos por imágenes más abstractas: estampas impresas en serie, primero, y, para la época de la coronación de Carlos III, la bandera real. Mientras la apelación a la figura de reinos y ciudades y a las representaciones pictóricas de los Habsburgos actualizaba la naturaleza 
plural y pactista de la monarquía, las reglas de ceremonial borbónicas evocaban la nueva concepción absolutista del poder real y la visión unitaria, homogeneizante, de sus súbditos. En esta misma dirección, hacia la década de 1780 se suprimió la antigua práctica de que el juramento de asunción de los virreyes se realizara en presencia del vecindario de Lima, comprometiéndose a respetar los fueros y privilegios de la ciudad; la ceremonia se trasladó al interior de la audiencia donde el nuevo virrey se comprometía ante los oidores a desempeñar correctamente su función de presidente del tribunal (Osorio, 2008). Al decir del Pablo Ortemberg: "El juramento ya no se hacía en el espacio público ante la autoridad municipal, sino en cuarto cerrado ante la autoridad judicial. La Audiencia desplazaba al cabildo y la sala del Acuerdo reemplazaba a la calle" (Ortemberg, 2014, p.87).

La Plata no estuvo exenta de estas transformaciones. En su incisivo libro sobre la sociedad charqueña tardocolonial, Eugenia Bridikhina concluye que "las fiestas, como espacio de comunicación que permitía expresar las pretensiones políticas locales en América, fueron paulatinamente convertidas en un espacio de expresión unívoca desplazada por las ideas y prácticas que relacionaban la felicidad pública y el bien del Estado con la imagen del Rey" (Bridikhina, 2007, p.358). La fiesta de San Carlos de 1781 aparece en marcada disonancia con estas tendencias (Serulnikov, 2008). Por lo pronto, el trasfondo de la celebración tuvo inequívocos tonos contenciosos puesto que estuvo precedida de meses de contiendas públicas de patricios y plebeyos con los ministros de la audiencia, de la exitosa resistencia del vecindario al establecimiento del estanco de tabaco, de las tensiones generadas por el arribo de una compañía de soldados peninsulares y, sobre todo, de falsos rumores acerca de un inminente motín popular contra los nuevos impuestos que los moradores atribuyeron a sus poderosos adversarios. Si para algo sirvió la fiesta, fue precisamente para poner de manifiesto las pretensiones políticas locales frente a los designios imperiales. Se resolvió así que la ceremonia girara ese año en torno a la fijación en los portales del edificio del cabildo de una placa de bronce "en que constan las proezas y trofeos de esta Ciudad y su Ilustre Ayuntamiento, gravándose juntamente en 
ella sus Armas". Se dispuso que la placa estuviera expuesta toda la tarde sobre un tablado en la plazuela frente al Hospital de Santa Bárbara para que el público la apreciara. Al atardecer, los alcaldes, alguaciles, regidores y otros oficiales marcharon en cabalgata hasta el lugar portando otro prominente emblema local: el estandarte de La Plata. Las connotaciones del acto no debieron haber sido menos legibles que la leyenda impresa en la placa. El estandarte había sido otorgado por los virreyes Marqués de Cañete y Francisco de Toledo en el siglo XVI a raíz del alineamiento de sus habitantes con el bando realista en las guerras civiles de la época.

Los múltiples hilos que enlazaban el pasado y el presente habían sido traídos a colación poco antes a raíz de dos representaciones colectivas elevadas a los tribunales superiores, una firmada por unos ciento setenta oficiales de los gremios de sastres, plateros, carpinteros, zapateros, herreros, silleros, sombreros y otras muchas "gentes del pueblo"; la otra, por abogados, comerciantes, mineros, clérigos, catedráticos y otros tantos moradores patricios. Allí, a efectos de desmentir a los magistrados y oficiales militares que, según se aseveró, procuraban suprimir los grandes méritos de la población local "para conseguir superioridad, distinción y preferencia”, se exaltó la reciente victoria del vecindario sobre los rebeldes indígenas y se exhibió una carta del ayuntamiento al virrey Francisco de Toledo de 1574, y la respuesta de éste, refrendando cómo la ciudad había defendido con enjundia a la Corona "en aquellos tiempos que contra ella se levantaron Gonzalo Pizarro, Francisco Carvajal y otros tiranos, y fue la única que no concurrió en rebelión alguna, aun estando conspiradas las más principales ciudades del Reino". ${ }^{9}$ La movilización del pueblo en la guerra contra kataris y amarus no representaba sino la continuidad de aquellos añejos servicios a la Corona durante las guerras civiles del siglo XVI. Un antiguo contrato de fidelidad había sido reactualizado y, con ello, "las mercedes y exenciones" que ese vínculo trasuntaba.

Volviendo al estandarte de la ciudad, en conformidad con las disposiciones de Toledo, todos los años, por turnos, un miembro del cabildo designado como alférez debía guardarlo en su casa. El traspaso de la

9 Representación del Procurador General de Charcas, 9 oct. 1781, AGI, Charcas 595. 
insignia era motivo de una ceremonia de homenaje vasallático que recuerda el origen medieval, pactista, de la relación entre el monarca y sus súbditos. Al recibirlo de manos de los dos alcaldes ordinarios del ayuntamiento, el alférez debía decir:

Vos señor, don fulano, hacéis pleito homenaje, como hombre caballero e hijodalgo, una dos y tres veces, al modo y fuero de España, en mis manos, de guardar y cumplir la fidelidad que debéis a Dios y al Rey, Nuestro Señor Natural, y a sus sucesores en la corona de Castilla y León, teniendo este estandarte de la ciudad que os entrego en tal fe, seguro de que sabréis guardarlo con todas vuestras fuerzas y primero perderéis la vida si fuese necesario por el dicho estandarte, defendiéndolo y amparándolo contra todos los hombres del mundo... (citado en Querejazu Calvo, 1987, p.115).

Los actos del 4 de noviembre de 1781 no dejaron de evocar estos orígenes. Es sabido que el recorrido de los cortejos y procesiones por lugares cargados de simbolismo construía un relato histórico y una imagen ideal de la sociedad. Es significativo entonces que las autoridades concejiles y los vecinos de honor que marcharon en cabalgata portando el estandarte desde el edificio del cabildo hasta la plazuela de Santa Bárbara lo hicieran por la calle de la parroquia de San Miguel: el día de San Miguel, 29 de septiembre, se recordaba la victoria sobre las fuerzas de Gonzalo Pizarro mediante una misa en la Catedral y una cabalgata ceremonial por el pueblo presidida por la insignia de la ciudad (Querejazu Calvo, 1987, p.116). Una vez que el cortejo arribó a Santa Bárbara, los regidores retiraron del tablado la placa con los méritos de la ciudad y se la entregaron a los dos alcaldes, quienes la colocaron sobre un coche en presencia de toda la concurrencia. Precedida por otro coche que llevaba el estandarte, fue luego conducida con música y salvas hasta los portales del ayuntamiento. Allí se había colocado un tercer objeto que, al igual que la placa y el estandarte, estaba impregnado de un simbolismo que remitía a otras épocas: el retrato del Carlos III. La ceremonia estuvo acompañada de tiros de cañones; "la considerable 
porción de gente" que se había congregado exclamaba por la vida del Rey, "aplaudiendo la fidelidad de la ciudad". Luego, se llevó a cabo una cabalgata por todo el pueblo. ${ }^{10}$

En la introducción a su magnífico libro sobre Sor Juana Inés de la Cruz, Octavio Paz escribió que la fiesta hispánica era la yuxtaposición de rito cívico, procesión religiosa y romería popular y una ocasión “en la que los símbolos políticos, al encarnar, hacían visible la doble relación que unía a la sociedad con el príncipe y consigo misma”. En palabras de Pierre Chaunu, constituía "la relación pública privilegiada de la monarquía. De ahí que desempeñe un papel capital en la construcción del Estado. La fiesta tiene un lugar especial en la Gran Historia” (Paz, 1995, p.197, p.199). Pues bien, si la función primordial del ceremonial era reafirmar los vínculos que unían al Rey con sus súbditos, considerando el acrimonioso clima político imperante y los conspicuos contrapuntos con los símbolos propios del absolutismo borbónico, la fiesta de Carlos III portaba mensajes notoriamente ambivalentes sobre los principios de legitimidad monárquica. Los motines populares contra las tropas peninsulares que estallaron en 1782 y 1785, la sucesión de cabildos abiertos y alegatos colectivos cuestionando abiertamente las decisiones de los más altos magistrados regios, en fin, la contumaz reivindicación del derecho de opinar sobre los asuntos públicos que llevó a que el ayuntamiento fuera tildado de sedicioso, debiera ser entendido no como la denegación sino el corolario de las fervientes proclamaciones de lealtad a la Corona.

\section{EL MONARQUISMO POPULAR}

\section{Y LA CRISIS DEL GOBIERNO ESPAÑOL}

En octubre de 1786, el virrey del Río de la Plata escribió al todopoderoso Ministro de Indias, José de Gálvez, que si meditaba por un instante en las implicancias de un cabildo abierto en el que se había debatido y censurado públicamente un oficio suyo expresando justificadas dudas acerca de la fidelidad del vecindario de La Plata durante la revuelta popular de

10 AGI, Charcas 595. 
1785, repararía que no se había tratado en rigor de un cabildo abierto sino más bien de una "Junta de vecinos que se formó en las mismas casas capitulares". ${ }^{11}$ Lo que el marqués de Loreto sugería aquí era que, a la sombra del autoproclamado amor al monarca, el antiguo edificio del ayuntamiento y la ilustre institución del cabildo abierto se habían tornado en escenarios de novedosas y sediciosas prácticas representativas, de juntas: un fenómeno de notorias resonancias en los tiempos venideros — en el Alto Perú en 1809 y en Buenos Aires un año después.

En efecto, las ambivalentes resonancias del monarquismo popular, así como la compleja imbricación entre tradición y radicalismo, saldría a la luz en toda su magnitud en el momento más crítico de la relación de la ciudad con la metrópoli: el levantamiento de La Plata del 25 de mayo de 1809 . Se trató, como es bien conocido, del primer conato de abierto de rebelión contralas autoridades peninsulares y virreinales en el ámbito del Río de la Plata luego de la invasión napoleónica a la península ibérica. Dejando de lado las tradicionales historias patrias, empeñadas en establecer la progenie de las nuevos estados nacionales, el evento ha tendido a ser pensado como una disputa facciosa entre los más altos funcionarios coloniales (un alzamiento de los oidores de la audiencia contra el intendente de Charcas y presidente del tribunal Ramón García Pizarro, el arzobispo Benito María Moxó y Francolí y el virrey de Buenos Aires), la cual contó con la activa participación de un grupo de abogados y letrados criollos de ideas radicales, la mayoría asociados a la Universidad de Charcas, y fue secundada por la movilización callejera de la plebe urbana que actuó como fuerza de choque contra la guarnición militar y en la deposición de las autoridades vigentes. El movimiento habría respondido a ambiciones personales de poder de los ministros y a los anhelos autonómicos regionales bis a bis la corte porteña, cuya superior jurisdicción administrativa y absorción de la plata altoperuana había sido resentida desde su misma instauración en 1776. El impulso ideológico profundo fue más conservador que innovador: el inveterado regalismo

11 El virrey marqués de Loreto al Ministro de Indias José de Gálvez, 13 oct. 1786, AGI, Buenos Aires 73 (subrayado nuestro). 
de la población urbana que afloró en reacción de la alegada complicidad del intendente García Pizarro y el arzobispo Moxó y Francolí con los planes de la infanta Carlota de Portugal para asumir la Regencia del Río de la Plata mientras durara el cautiverio de su hermano Fernando VII. Los putativos promotores del célebre proyecto carlotino fueron el enviado de la Junta de Sevilla, el militar arequipeño José Manuel de Goyeneche, y el virrey del Río de la Plata, Santiago de Liniers. ${ }^{12}$

Si bien esta sinopsis puede dar cuenta de los contornos generales del acontecimiento, habría que remarcar que por sus raíces históricas, su dinámica política y su composición social, el acontecimiento fue algo más, $\mathrm{y}$ algo muy distinto, a una mera lucha jurisdiccional y facciosa, seguida de una asonada popular, en torno a la más adecuada forma de defender los derechos de la Corona española en una excepcional situación de acefalia regia. El virrey del Río de la Plata Baltasar Hidalgo de Cisneros, quien sucedió a Liniers a mediados de 1809, como los intendentes altoperuanos y todos aquellos interesados en preservar el status quo, lo comprendió de inmediato. A semejanza del marqués de Loreto veinte años atrás, la proclamada lealtad al monarca de la población charqueña no le causó la menor impresión. Sabía perfectamente que en América el rey era un emblema tan abstracto y universal, tan carente de las determinaciones materiales y simbólicas propias de los órganos de gobierno, que su invocación podía albergar proyectos y prácticas políticas de la más variada índole. Virtualmente todas las rebeliones y alzamientos se habían justificado en su nombre, incluyendo, como acabamos de ver, la más radical y sediciosa de todas, la revolución panandina de 1780. Era plenamente consciente, además, que la ciudad había estado enfrascada por años en una larga secuencia de conflictos políticos que involucraron a todas las corporaciones y magistraturas (el ayuntamiento, la universidad, la audiencia, el intendente, el arzobispado) y que las discordias en torno a la presunta conspiración carlotina había sido deliberadamente

12 Sobre los eventos de La Plata de 1809, véase QUEREJAZU CALVO, 1987, p.519-616; SILES SALINAS, 1992, p.123-145; JUST LLEÓ, 1994; ROCA, 1998, P.145-208; SOUX MUÑOZ REYES, 2008, p.465-489; SERULNIKOV, 2012. 
sobredimensionada a efectos de deslegitimar a las autoridades constituidas - un eslabón más de la cadena. En un oficio secreto a los oidores de la audiencia, erigida por entonces en "audiencia gobernadora", les recordó que su alegado objetivo de "mantener los verdaderos derechos de

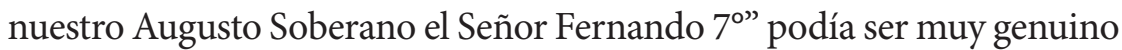
y muy loable, pero resultaba del todo incompatible con el irrevocable menoscabo que estaban causando a los dos pilares fundamentales sobre los que la fidelidad al rey se asentaba: la "subordinación a los superiores" y el "orden público" (citado en Just Lleó, 1994, p.154). De no otra cosa se trataba la violenta deposición del intendente García Pizarro y del arzobispo Moxó; el ataque a los soldados del ejército regular y su reemplazo por compañías de milicias de patricios y plebeyos; el ambiente general de deliberación sobre la legitimidad del gobierno; la posición de poder asumida por los vecinos (doctores de la universidad, oficiales del cabildo, familias distinguidas criollas); el despacho de comisionados a otras ciudades para obtener su adhesión al alzamiento; $y$, por supuesto, la movilización de las clases populares. Se diría entonces que, en nombre de la fidelidad al depuesto monarca, tres principios básicos de la cultura política colonial fueron puestos en cuestión: la politización de las relaciones de mando y obediencia (no la segunda sino la primera cláusula de la más acendrada máxima de la administración indiana, "se obedece pero no se cumple"), el carácter reservado de los asuntos de gobierno y el activo involucramiento de las clases bajas en las cuestiones públicas.

Para los propósitos de este estudio, es interesante señalar que, al igual que dos décadas antes, las representaciones simbólicas de legitimismo monárquico volvieron a operar como un vehículo de resistencia popular a los superiores. No se trata naturalmente de minimizar el fenomenal impacto de la coyuntura abierta a ambos lados del Atlántico por las abdicaciones de Bayona, la cual planteó dilemas y posibilidades impensables hasta entonces. Pero sí llamar la atención sobre el hecho de que las reacciones colectivas a las inéditas circunstancias abrevó de definidas experiencias políticas preexistentes. Así pues, se adoptó la costumbre de colocar todas las tardes un retrato de Fernando VII en los bajos del cabildo, frente a la Plaza Mayor. Allí se congregaba diariamente 
el "cholerío" para cantar, gritar, dar vivas y mueras (Just Lleó, 1994, p.141). Era una práctica que nos retrotrae a las contiendas de finales de 1781 cuando la colocación del retrato de Carlos III en los bajos del cabildo, junto con la fijación de una placa de bronce que glorificaba "las proezas y trofeos de la Ciudad y su Ilustre Ayuntamiento" en defensa de la monarquía en tiempos de las guerras contra los encomenderos del siglo XVI y los insurgentes indígenas del XVIII, había personificado el rechazo a las políticas de control imperial que Carlos III y sus ministros estaban impulsando. Al igual que en el pasado, la exaltación del poder del rey en las fiestas lejos de constituir un acto de sumisión al orden establecido, funcionó como la reafirmación, en espejo, del poder de quienes las organizaban y promovían (Bridikhina, 2007). El vasto potencial contestatario de las expresiones de monarquismo popular llevó a que, tras el 25 de mayo de 1809, en medio de una creciente polarización del conflicto con los máximos magistrados españoles, la celebración pública de Fernando VII se tornara un ritual cotidiano.

También la celebración de Corpus Christi sirvió a este fin. Era costumbre inmemorial que los gremios de oficios y mercaderes levantaran ese día altares callejeros por los sitios donde pasaba la procesión y que costearan las compañías de danzantes, los disfraces y las bebidas que allí se ofrecían. Aunque los onerosos gastos suscitaron en ocasiones quejas, cuando las autoridades borbónicas intentaron simplificar las festividades, los artesanos se opusieron obstinadamente a que se alterara la tradición (Querejazu Calvo, 1987). En 1809, la ceremonia no solo contó con una explosión de fervor popular, sino que además adquirió un palmario tono político: en la víspera de la fiesta de Corpus, según un relato de la época, el pueblo recorrió las calles de la ciudad cantando

con música de guitarras coplas muy deshonestas, turbulentas e injuriosas a las señora Princesa del Brasil Doña Carlota Joaquina de Borbón, y contra los Señores Virrey, Presidente [García Pizarro], Arzobispo y [intendente de Potosí Francisco de Paula] Sanz, tratándolos de traidores con el estribillo Viva el Rey, el que repetían con algazara aun en la misma retreta” (citado en Just Lleó, 1994, p.133). 
Para muchos otros defensores de la Corona, estas vivas al Rey debieron sin duda aparecer como la antítesis de lo que la monarquía constituía. Y ese es quizás el secreto último del monarquismo. No hay monarquismos auténticos y monarquismos ingenuos: solo monarquismos incompatibles entre sí.

A modo de cierre, cabría recordar aquí la hipótesis planteada por el antropólogo Claudio Lomnitz respecto de la función del ceremonial en la construcción del imaginario político en el mundo hispánico. En un ensayo sobre la fiesta en México, sostiene que, "el ritual es un foro crítico para la construcción de arreglos pragmáticos donde no existen formas abiertas de comunicación y de toma de decisiones. En otras palabras, existe una correlación inversa entre la importancia política del ritual y la importancia de la esfera pública" (Lomnitz, 2000, p.260). Si la observación posee un indudable valor heurístico en la larga duración, los casos aquí analizados sugieren que en momentos de crisis de legitimidad, la intensificación del ritual y el ceremonial, asociados como estaban al enaltecimiento de la figura del monarca, mantenían una correlación directa, no inversa, con la explosión de la esfera pública, con la multiplicación de ámbitos de debate abierto y horizontal sobre los asuntos de Estado. Es una idea que se hace eco de lo señalado por Peter Guardino en su estudio sobre los sectores populares de la ciudad de Oaxaca durante la transición de la colonia a la independencia. Afirma allí que el impacto social y político de los levantamientos campesinos de Miguel Hidalgo y José María Morelos fue tan significativo del bando realista como del insurgente, ya que la movilización de los moradores de Oaxaca en defensa del monarca acabó por expandir decisivamente el ámbito legítimo de intervención de la población en general, y los sectores plebeyos en particular, en los asuntos públicos. Durante la década de 1810, estimulado por las elecciones de representantes para las Cortes de Cádiz y las sucesivas reformas liberales, se iba a conformar una novedosa escena política que dio nacimiento a la formación de dos 
partidos o facciones (los “aceites" y "vinagres") y a un proceso de politización popular del que ya no habría retorno. Así pues, las derivaciones de la militarización contra-revolucionaria y el monarquismo no fueron necesariamente menores que las de la militarización revolucionaria y los anhelos emancipadores.

La idea cada vez más popular de que todos los hombres adultos eran, en un sentido esencial, políticamente iguales, que tenían un compartido interés en el sistema político", había traspasado las trincheras. "El movimiento hacia la igualdad política - concluye el autor - no estaba ligado de ninguna manera fundamental a la cuestión de si México debía ser un nación independiente (Guardino, 2005, p. 154).

En definitiva, lo que el caso de Oaxaca nos dice, y lo que este ensayo ciertamente ha procurado decir, es que cuando se miran las mutaciones estructurales de la cultura política en el ocaso del dominio español, los impulsos regalistas o independentistas de la población resultan en buena medida irrelevantes. El monarquismo de los pueblos andinos y de los criollos y mestizos de La Plata, aunque antagónicos entre sí, contenían en su seno la capacidad de motorizar masivos procesos de contestación $\mathrm{y}$, potencialmente, de derivar en una subversión radical de los modos establecidos de hacer política y del lugar de los súbditos en el marco del imperio. Reflexionando sobre el impacto interno de la ocupación inglesa de Buenos Aires en 1806 y 1807, Tulio Halperín Donghi subrayó que el traumático evento había enseñado "un nuevo tipo de relación con la autoridad suprema en la que es ésta la que solicita - con la amenaza, con la promesa - una adhesión que antes ni siquiera se había discutido; les enseñó a descubrir una nueva dimensión para las actividades de las corporaciones y magistraturas, más estrictamente política, ausente en el pasado". De ese proceso de politización al impacto de las abdicaciones de Bayona, y luego a la Revolución de Mayo, hubo una línea recta: "nada de lo que ocurrió hasta 1810", nos recuerda, "podría invitarlos a dudar de la verdad esencial de este descubrimiento" (Halperín Donghi, 1972, p.144-145). Nuestra cronología es de otra profundidad temporal pero 
el concepto es semejante. Es a lo que apunta el texto del escritor polaco Ryszard Kapuściński sobre la Etiopía de Haile Selassie, que sirve de epígrafe de este artículo en tanto alegoría del poder absoluto, del poder ejercido sin mediación de instituciones representativas ni referencia a la voluntad popular. "En palacio las preguntas solo se podían hacer de arriba abajo, nunca al revés", reporta: "en el momento en que por primera vez sonó una pregunta planteada en dirección opuesta a la acostumbrada sonó también la señal de la revolución” (Kapuściński, 2004, p.17).

Unos dos siglos antes, en 1787, un alto funcionario virreinal porteño explicó al Ministro de Indias que los vecinos de La Plata, amparados en su exaltada lealtad a la Corona, se prodigaban en desconocer su deber primario hacia la misma: "la rigurosísima obligación de callar hasta que fuesen preguntados". ${ }^{13}$ Que los vasallos se arrogaran la potestad de opinar con libertad, sin tapujos, de los asuntos de gobierno aparecía como un pecado capital, una proposición inadmisible. Retrospectivamente, fue también irrefrenable e irreversible. Los fundamentos ideológicos del colonialismo y el absolutismo monárquico terminaron siendo desmantelados en nombre del rey y de sus leyes antes, en ocasiones mucho antes, de que lo fueran sus propios derechos soberanos.

\section{REFERENCIAS BIBLIOGRÁFICAS}

ANDERSON, Perry. Pesquisa nocturna: Carlo Ginzburg, Secuencia, n. 29, 1994, p.191-217.

BORAH, Woodrow. Justice by Insurance. The General Indian Court of Colonial Mexico and the Legal Aides of the Half-Real. Berkeley: University of California Press, 1983.

BRIDIKHINA, Eugenia. Theatrum Mundi. Entramados del poder en Charcas colonial. La Paz: Plural Ediciones, 2007.

BURKE, Peter. Popular Culture in Early Modern Europe. London: Temple Smith, 1978.

13 El asesor letrado del virrey Loreto, Miguel Sánchez Moscoso, a José de Gálvez, 12 abr. 1787, AGI, Buenos Aires 153. 
CAHILL, David. Genocide from Below. The Great Rebellion of 1780-82 in the Southern Andes. En: MOSES, A. Dirk (ed.). Empire, Colony, Genocide: Conquest, Occupation, and Subaltern Resistance in World History. New York: Berghahn Books, 2008.

CAJÍAS DE LA VEGA, Fernando. Oruro 1781: Sublevación de indios y rebelión criolla. Lima: IFEA-IEB, 2004.

CALHOUN, Craig Jackson. The Radicalism of Tradition: Community Strength or Venerable Disguise and Borrowed Language? American Journal of Sociology, vol. 88, n. 5, 1983, p.886-914.

COATSWORTH, John. Patrones de rebelión rural en América Latina: México en una perspectiva comparativa. En KATZ, Friedrich (comp.). Revuelta, rebelión y revolución. La lucha rural en México del siglo XVI al siglo XX. México: Ediciones Era, 1990. p.27-64.

CURCIO-NAGY, Linda A.. The Great Festivals of Colonial Mexico City. Performing Power and Identity. Albuquerque: University of New Mexico Press, 2004.

CHARTIER, Roger. Espacio público y desacralización en el siglo XVII. Los orígenes culturales de la Revolución Francesa. Barcelona: Gedisa, 1995. CHATTERJEE, Partha. The Nation and Its Fragments. Colonial and Postcolonial Histories. Princeton, Princeton University Press, 1993.

ECHEVERRI, Marcela. Indian and Slave Royalists in the Age of Revolution: Reform, Revolution, and Royalism in the Northern Andes, 1780-1825. New York: Cambridge University Press, 2016.

FARGE, Arlette. Subversive Words. Public Opinión in Eighteenth-Century France. University Park: The Pennsylvania State University Press, 1992. FIELD, Daniel. Rebels in the Name of the Tsar. Boston, MA: Houghton Mifflin, 1976.

FISHER, John, La rebelión de Túpac Amaru y el programa imperial de Carlos III. En: FLORES GALINDO, Alberto (ed.) Túpac Amaru II-1780, Lima, 1976, p.107-128.

GARRETT, David. Shadows of Empire: The Indian Nobility of Cusco, 17501825. Cambridge: Cambridge University Press, 2005. 
GARRIGA, Carlos. Continuidad y cambio del orden jurídico. En: GARRIGA, Carlos (coord.). Historia y Constitución. Trayectos del constitucionalismo hispano. México: CIDE, 2010, p.59-106.

GUARDINO, Peter. The Time of Liberty: Popular Political Culture in Oaxaca, 1750-1850. Durham: Duke University Press, 2005.

GUERRA, François-Xavier. Modernidad e independencias. Ensayos sobre las revoluciones hispánicas. México: MAPFRE, 1992.

HALPERÍN DONGHI, Tulio. Revolución y guerra. Formación de una élite dirigente en la Argentina criolla. México: Siglo Veintiuno Editores, 1972. HALPERIN DONGHI, Tulio. Reforma y disolución de los imperios ibéricos, 1750-1850. Madrid: Alianza Editorial, 1985.

HALPERÍN DONGHI, Tulio. Tradición política española e ideología revolucionaria de Mayo. Buenos Aires: Prometeo, 2009.

HOBSBAWM, Eric. Peasant Politics. Journal of Peasant Studies, n. 1, p.3-22, 1973.

JUST LLEÓ, Estanislao.Comienzo de la independencia en el Alto Perú: los sucesos de Chuquisaca, 1809. Sucre: Editorial Judicial, 1994.

KAPUŚCIŃSKI, Ryszard. El Emperador. Barcelona: Anagrama, 2004.

KATZ, Friedrich. Las rebeliones rurales en el México precortesiano y colonial. En KATZ, Friedrich (comp.). Revuelta, rebelión y revolución. La lucha rural en México del siglo XVI al siglo XX. México: Ediciones Era, 1990, p.65-93.

KOSELLECK, Reinhart. Futuro pasado: para una semántica de los tiempos histórico. Madrid: Paidos, 1993.

LASSO, Marixa. Mitos de armonía racial. Raza y republicanismo durante la era de la revolución, Colombia 1795-1831. Bogotá: Universidad de los Andes/Banco de la República, 2013.

LEWIN, Boleslao. La rebelión de Túpac Amaru y los orígenes de la emancipación americana. Buenos Aires: Hachette, 1957.

LOMNITZ, Claudio. Ritual, rumor y corrupción en la conformación de los "sentimientos de la nación". En LOMNITZ Claudio (coord.). Vicios públicos, virtudes privadas: la corrupción en México. Centro de Investigaciones y Estudios Superiores en Antropología Social: México, 2000. 
LUEBKE. David M. Naïve Monarchism and Marian Veneration in Early Modern Germany. Past \& Present, n. 154, p.71-106, feb. 1997.

MACLACHLAN, Colin M. Spain's Empire in the New World: The Role of Ideas in Institutional and Social Change. Berkeley: University of California Press, 1988.

MAMONOVA, Natalia. Naive Monarchism and Rural Resistance in Contemporary Russia. Rural Sociology, v. 00, n. 00, p.1-27, 2016.

MARX, Karl. El 18 Brumario de Luis Bonaparte. Madrid: Fundación Federico Engels, 2003.

MÉNDEZ, Cecilia. La república plebeya. Huanta y la formación del Estado peruano, 1820-1850. Lima: Instituto de Estudios Peruanos, 2014.

O'PHELAN GODOY, Scarlett. Un siglo de rebeliones anticoloniales. Perú y Bolivia 1700-1783. Cusco: Centro Bartolomé de las Casas, 1988.

ORTEMBERG, Pablo. Rituales del poder en Lima (1735-1828). De la Monarquía a la República. Lima: Pontificia Universidad Católica del Perú, 2014. OSORIO, Alejandra B. Inventing Lima: Baroque Modernity in Peru's South Sea Metropolis. New York: Palgrave Macmillan, 2008.

OWENSBY, Brian P. Empire of Law and Indian Justice in Colonial Mexico. Stanford: Stanford University Press, 2008.

PALTI, Elías J. Los orígenes intelectuales de la revolución de independencia como "historia de efectos". Introducción a HALPERÍN DONGHI, Tulio. Tradición política española e ideología revolucionaria de Mayo. Buenos Aires: Prometeo, 2009.

PAQUETTE, Gabriel B. Enlightenment, Governance, and Reform in Spain and its Empire, 1759-1808. Cambridge: Palgrave Macmillan, 2008.

PAZ, Octavio. Sor Juana Inés de la Cruz o las trampas de la fe. México: FCE, 1995.

PERRIE, Maureen. Pretenders and Popular Monarchism in Early Modern Russia: The False Tsars of the Time and Troubles. Cambridge: Cambridge University Press, 1995.

PHELAN, John Leddy. The People and the King: The Comunero Revolution in Colombia, 1781. Madison: University of Wisconsin Press, 1978.

PLATT, Tristan. Estado boliviano y ayllu andino. Tierra y tributo en el norte de Potosí. Lima: IEP, 1982. 
QUEREJAZU CALVO, Roberto. Chuquisaca, 1539-1825. Sucre: Imprenta Universitaria, 1987.

RANCIÈRE, Jacques. Nights of Labor: The Workers Dream in Nineteenth Century France. Philadelphia: Temple University Press, 1991.

ROCA, José Luis. 1809. La revolución de la Audiencia de Charcas en Chuquisaca y en La Paz. La Paz: Plural Editores, 1998.

SCOTT, James C. Los dominados y el arte de la resistencia. Discursos ocultos. México: Ediciones Era, 2000.

SERULNIKOV, Sergio. Conflictos sociales e insurgencia en el mundo colonial andino. El norte de Potosí, siglo XVIII. Buenos Aires: Fondo de Cultura Económica, 2006.

SERULNIKOV, Sergio. El fin del orden colonial en perspectiva histórica. Las prácticas políticas en la ciudad de La Plata, 1781-1785 y 1809. Revista Andina, Cusco, n. 52, p.9-47, 2012.

SERULNIKOV, Sergio. La lógica del absolutismo. Vecinos y magistrados en Charcas en tiempos del reformismo borbónico. Colonial Latin American Review, vol. 26 n. 3, p.355-385. 2017.

SERULNIKOV, Sergio. "'Las proezas de la Ciudad y su Ilustre Ayuntamiento': Simbolismo político y política urbana en Charcas a fines del siglo XVIII". Latin American Research Review, vol. 43, n. 3, 2008, p.137-165.

SERULNIKOV, Sergio. Patricians and Plebeians in Late Colonial Charcas: Identity, Representation, and Colonialism. En: FISHER, Andrew B.; O'HARA, Matthew D. (eds.). Imperial Subjects: Race and Identity in Colonial Latin America. Durham: Duke University Press, 2009. p.167-196. SERULNIKOV, Sergio. Tulio Halperín Donghi y la independencia hispanoamericana. Boletín del Instituto de Historia Argentina y Americana "Dr. Emilio Ravignani”. Tercera serie, Número Especial, p.132-154, 2018.

SEWELL, William Hamilton. Work and Revolution in France: The Language of Labor from the Old Regime to 1848. Cambridge: Cambridge University Press, 1980.

SILES SALINAS, Jorge. La independencia de Bolivia. Madrid: MAPFRE, 1992. SKINNER, Quentin. The Foundations of Modern Political Thought. Cambridge: Cambridge University Press, 1979. 
SOUX MUÑOZ REYES, María Luisa. La Audiencia de Charcas y los acontecimientos de 1808: rumores y tensiones en una sociedad provincial. En: AVILA A.; PÉREZ HERRERO, P. (comp). Las experiencias de 1808 en Iberoamérica. Alcalá de Henares: Universidad de Alcalá, 2008. p.465-489. STERN, Steve. Los pueblos indígenas del Perú y el desafío de la conquista española. Madrid: Alianza, 1986.

TAYLOR, William. Drinking, Homicide, and Rebellion in Colonial Mexican Villages. Stanford: Stanford University Press, 1979.

TAYLOR, William. Between Global Process and Local Knowledge. An Inquiry into Early Latin American Social History, 1500-1900. En: Olivier Zunz (ed.). Reliving the Past. The Worlds of Social History. Chapel Hill: The University of North Carolina Press, p.115-190,1985.

TAYLOR, William. Magistrates of the Sacred. Priests and Parishioners in Eighteenth-Century Mexico. Stanford: Stanford University Press, 1996. THOMPSON, Edward Palmer. La formación de la clase obrera en Inglaterra. Barcelona: Crítica, 1989.

VAN YOUNG, Eric. La otra rebelión. La lucha por la independencia de México, 1810-1821. México: Fondo de Cultura Económica, 2006.

WALKER, Charles, F. Smoldering Ashes. Cuzco and the Creation of Republican Peru, 1780-1840. Durham: Duke University Press, 1999.

WALKER, Charles F. La rebelión de Túpac Amaru. Lima: Instituto de Estudios Peruanos, 2015.

ZARET, David. Petitions and the "Invention" of Public Opinion in the English Revolution. American Journal of Sociology, vol. 101, n. 6, p.1497-1555, 1996. 